\title{
KEKUATAN HUKUM JUAL BELI TANAH MELALUI SEORANG KUASA
}

Oleh:

\author{
Rumelda Silalahi \\ Universitas Darma Agung, Medan \\ E-Mail : \\ rumeldasilalahi88@gmail.com
}

\begin{abstract}
This study aimed at determining the legal strength of land sale and purchase through the power of an attorney. The method used in this study was sociological juridical, in which the author examined the fact based on the legislation that regulates the problem by looking directly at the implementation and application of these regulations in practice. The method of data analysis in this study was analytical descriptive wherein in this process the researcher actively and subjectively performed the process of interpreting, interpreting, and evaluating the collected data based on the theoretical framework and understanding that developed when interpreting the data. The results of the research obtained showed that the sale and purchase of land through the power of an attorney had a legal force that was legal and bound the authority and the third party concerned had to carry out the contents of the agreement. This was because the authorizer had to implement the agreement made by the recipient of the power of an attorney, as long as the recipient of the power did not exceed the authority granted to him. If there was a dispute, the party who become the party was the authorizer and the third party was not the recipient of the power of the attorney. Whereas the problems arising in connection with the sale and purchase of land through the power of an attorney in a court hearing stipulated the provisions of the Civil Code, UUPA No. 51960 and Government Regulation No. 10 of 1961 concerning land registration.
\end{abstract}

Keywords: legal strength, land purchase and power

\section{PENDAHULUAN}

\subsection{Latar Belakang}

Dalam memenuhi kebutuhan-

kebutuhan manusia di dalam masyarakat, individu yang satu senantiasa berhubungan dengan individu yang lain. Dengan perhubungan tersebut diharapkan kebutuhan yang dikehendaki individu yang satu akan dipenuhi oleh individu yang lain, demikian pula sebaliknya secara timbal balik. Perjanjian merupakan wujud dari hubungan kerjasama yang mengikat antara dua individu atau lebih.

Hukum perjanjian bersifat terbuka atau mempunyai satu asas kebebasan berkontrak, artinya kebebasan yang diberikan seluas-luasnya kepada siapapun untuk mengadakan perjanjian yang berisi apa saja, asalkan tidak melanggar undang-undang, ketertiban umum, dan kesusilaan. Para pembuat perjanjian boleh membuat ketentuan-ketentuan sendiri yang menyimpang dari Pasal-Pasal dalam hukum perjanjian. Pasal-pasal dari hukum perjanjian bersifat pelengkap, yang berarti pasal-pasal tersebut dapat dikesampingkan manakala dikehendaki oleh pihak-pihak yang membuat suatu perjanjian. Kalau mereka tidak mengatur sendiri sesuatu hal, berarti hal tersebut akan tunduk pada undang-undang yang berlaku (Subekti, 2002 : 13).

Sistem terbuka ini dalam Kitab Undang-Undang Hukum Perdata, 
lazimnya disimpulkan dalam Pasal 1338 ayat (1), yang berbunyi "semua perjanjian yang dibuat secara sah berlaku sebagai undang-udang bagi mereka yang membuatnya".

Dalam beberapa perjanjian yang timbul dalam masyarakat, perjanjian jual beli semakin lama makin penting untuk memenuhi kebutuhan-kebutuhan manusia di dalam masyarakat. Adapun yang dapat dijadikan perjanjian jual beli sangat banyak, baik benda bergerak maupun benda tetap. Jual beli benda bergerak dapat berupa jual beli kendaran seperti mobil, dan jual beli benda tetap contohnya adalah jual beli tanah. Dengan perkembangan penduduk yang meningkat seperti saat sekarang ini, terjadi keterbatasan tersedianya lahan atau tanah yang ada, karena tanah yang tersedia dari waktu ke waktu tidak pernah bertambah, sementara kebutuhan akan tanah atau lahan semakin tinggi. Untuk mendapatkan tanah sekarang ini juga bukanlah hal yang mudah di tengah tingginya kebutuhan akan tanah, terutama untuk wilayah perkotaan. Salah satu cara yang digunakan untuk mendapatkan tanah saat ini melalui jual beli.

Dalam melakukan jual beli tanah dibutuhkan akta otenik. Tanpa akta otentik secara hukum pengalihan hak atas tanah dan bangunan tidak sah secara hukum. Melalui akta otentik yang menentukan secara jelas hak dan kewajiban, menjamin kewajiban hukum, dan diharapkan pula dapat dihindari pula terjadinya sengketa (Supriadi, 2008 : 29).

Jual beli yang dahulu dikenal dengan asas riil terjadi jika sudah terjadi levering atau penyerahan barang. Keadaan tersebut berbeda dengan ketentuan tentang perjanjian jual beli yang diatur dalam Kitab Undang-Undang Hukum Perdata, karena sesuai dengan Pasal 1458 Kitab Undang-Undang Hukum Perdata. Atas dasar pasal tersebut, terlihat bahwa perjanjian telah ada sejak kata sepakat. $\begin{array}{cll}\text { Sebuah } & \text { perjanjian untuk } \\ \text { pelepasan hak atas tanah harus }\end{array}$ memenuhi kriteria terang dan tunai, sebagaimana ketentuan hukum adat yang diakomodir dalam Pasal 5 UndangUndang No. 5 Tahun 1960 tentang Peraturan Dasar Pokok-Pokok Agraria. Untuk kasus jual beli tanah yang belum memenuhi persyaratan terang dan tunai, maka instrument hukum yang digunakan adalah Perjanjian Pengikatan Jual Beli (PPJB) yang dilakukan dihadapan notaris. Perjanjian Pengikatan Jual Beli yang dibuat dihadapan notaris merupakan kesepakatan para pihak berdasarkan Pasal 1320 jo Pasal 1338 Kitab Undang-Undang Hukum Perdata sehingga memberikan kepastian dan perlindungan hukum bagi pihak yang membuatnya. Perjanjian Pengikatan Jual Beli (PPJB) merupakan ikatan awal antara penjual dan pembeli dalam bertransaksi, dan harus ditindaklanjuti dengan pembuatan Akta Jual Beli (AJB), karena PPJB belum mengalihkan hak secara hukum.

Pemberian kuasa (lastgeving) merupakan suatu perjanjian dengan mana seorang memberikan kekuasaan (wewenang) kepada seorang lain, yang menerimannya, untuk atas namanya menyelenggarakan suatu urusan. Ketentuan mengenai pemberian kuasa ini diatur dalam KUHPerdata, yaitu Buku III Bab XVI mulai dari Pasal 1792 hingga Pasal 1819. Kuasa (volmacht) tidak diatur, baik secara khusus dalam KUHPerdata tersebut maupun dalam ketentuan Undang-Undang lainnya, tetapi diuraikan sebagai salah satu bagian dari pemberian kuasa (Budiono, $2008: 2$ ).

Disebut pemberian kuasa jika pemberi kuasa melimpahkan perwakilan atau mewakilkan kepada penerima kuasa untuk mengurus kepentingannya, sesuai dengan fungsi dan kewenangan yang ditentukan dalam surat kuasa. Dengan demikian, penerima kuasa berkuasa penuh bertindak mewakili pemberi kuasa terhadap pihak ketiga untuk dan atas nama pemberi kuasa. Jadi dengan 
demikian pemberi kuasa bertanggung jawab penuh atas segala perbuatan kuasa sepanjang perbuatan yang dilakukan kuasa tidak melebihi wewenang yang diberikan pemberi kuasa.

Sesuai dengan perkembangan jual beli di dalam masyarakat maka penulis memilih judul : Kekuatan Hukum Jual Beli Tanah Melalui Seorang Kuasa, yang mana seorang itu (si pemberi kuasa) telah memberikan wewenang kepada seseorang (si penerima kuasa) sehingga sipenerima kuasa berhak terhadap sesuatu barang yang telah diberikan kuasa tadi kepadanya.

\subsection{Tujuan Penelitian}

Penelitian ini bertujuan untuk mengetahui kekuatan hukum jual beli tanah melalui seorang kuasa.

\section{METODE PELAKSANAAN}

Metode yang digunakan dalam penulisan ini adalah yuridis sosiologis, yang mana penulis meneliti berdasarkan peraturan perundang-undangan yang mengatur mengenai permasalahan dengan melihat langsung pelaksanaan dan penerapan dari peraturan tersebut dalam praktek. Metode analisis data pada penulisan ini adalah deskriptif analitis dimana dalam proses ini peneliti secara aktif dan subyektif melakukan proses tafsir, interpretasi, dan evaluasi data yang dikumpulkan berdasarkan kerangka teori dan pemahaman yang berkembang saat menafsirkan data.

\section{Uraian Teoritis}

\subsection{Pengertian Perjanjian}

Pengertian perjanjian secara umum dapat dilihat dalam Pasal 1313 ayat (1) KUHPerdata yang menyebutkan bahwa perjanjian adalah sesuatu perbuatan dengan mana satu orang atau lebih mengikatkan dirinya terhadap satu orang lain atau lebih. Dari Pasal 1313 ayat (1) KUH Perdata, dapat diketahui bahwa suatu perjanjian adalah suatu peristiwa dimana seorang berjanji kepada orang lain atau dimana dua orang atau lebih saling berjanji untuk melaksanakan suatu hal.

Menurut Suryono (2014 : 45) pengertian perjanjian sebagai mana tersebut dalam Pasal 1313 KUHPerdata terlalu luas, karena istilah perbuatan yang dipakai dapat mencakup juga perbuatan melawan hukum dan perwakilan sukarela, padahal yang dimaksud adalah perbuatan melawan hukum. Menurut Mahudi dan Ali (2001: 35) perjanjian adalah suatu hubungan atas dasar hukum kekayaan (vermogenscrechtlijke bettrecking) antara dua pihak, dimana pihak yang satu berkewajiban memberikan suatu prestasi atas nama pihak yang lain mempunyai hak terhadap prestasi itu. Prodjodikoro (1985 : 11) memberikan definisi bahwa perjanjian itu merupakan suatu perbuatan hukum mengenai harta benda kekayaan antara dua pihak, dimana satu pihak berjanji atau dianggap berjanji untuk melakukan suatu hal atau tidak melakukan suatu hal, sedang pihak yang lain berhak menuntut pelaksanaan janji itu.

Berdasarkan definisi yang telah dikemukakan tersebut di atas, maka dapat disebutkan bahwa perjanjian adalah hubungan hukum antara dua pihak atau lebih dimana pihak yang satu berjanji untuk melaksanakan sesuatu hal dan pihak yang lain berhak menuntut hal (prestasi) tersebut.

Pengertian jual beli dalam kehidupan sehari-hari dapat diartikan suatu perbuatan dimana seseorang melepaskan uang untuk mendapatkan barang yang dikehendaki secara sukarela. Jual beli yang dianut di dalam Hukum Perdata hanya bersifat obligator, yang artinya bahwa perjanjian jual beli baru meletakkan hak dan kewajiban timbal balik antara kedua belah pihak, penjual dan pembeli, yaitu meletakkan kepada penjual kewajiban untuk menyerahkan hak milik atas barang yang dijualnya, sekaligus memberikan kepadanya hak untuk menyerahkan hak 
milik atas barang yang dijualnya, sekaligus memberikan kepadanya hak untuk menuntut pembayaran harga yang telah disetujui, dan disebelah lain meletakkan kewajiban kepada si pembeli untuk membayar harga barang sebagai imbalan haknya untuk menuntut penyerahan hak milik atas barang yang dibelinya. Atau dengan perkataan lain, bahwa jual beli yang dianut dalam Hukum Perdata, jual beli belum memindahkan hak milik.

Di sini dapat diartikan juga bahwa jual beli adalah suatu persetujuan kehendak, antara penjual/pembeli mengenai suatu barang dan harga. Karena tanpa barang yang akan dijual dan tanpa harga yang dapat disetujui antara dua belah pihak, tidak mungkin ada jual beli, atau jual beli tidak pernah ada.

\subsection{Pengertian Perjanjian Jual Beli}

Pengertian perjanjian pengikatan jual beli dapat dilihat dengan cara memisahkan kata dari Perjanjian pengikatan jual beli menjadi perjanjian dan pengikatan jual beli. Perjanjian pengertiannya dapat dilihat pada sub bab sebelumnya, sedangkan Pengikatan Jual Beli pengertiannya menurut Subekti (1995 : 75) dalam bukunya adalah suatu perjanjian antara pihak penjual dan pembeli mengikatkan dirinya untuk menyerahkan suatu kebendaan dan pihak yang lain untuk membayar harga yang telah dijanjikan. Sedangkan menurut Budiono (2004 : 37), perjanjian pengikatan jual beli adalah perjanjian bantuan yang berfungsi sebagai perjanjian pendahuluan yang bentuknya bebas.

Menurut Surbekti (2006 : 366) mengatakan " Jual beli adalah suatu perjanjian bertimbal balik dalam mana pihak yang satu (sipenjual) berjanji untuk menyerahkan hak milik atas suatu barang, sedangkan yang lainnya (si pembeli) berjanji untuk untuk membayar harga yang terdiri atas sejumlah uang sebagai imbalan dari perolehan hak milik tersebut".
Dari defenisi di atas dapat diketahui bahwa harga barang tersebut harus berupa uang, maka tidak terjadi jual beli, melaikan yang terjadiadalah tukar menukar.

Menurut Suryodiningrat (1996 : 14) adalah bahwa "perjanjian jual beli adalah perjanjian/persetujuan/kontrak dimana satu pihak (penjual) mengikat diri untuk menyerahkan hak milik atas benda/barang kepada pihak lainnya (pembeli) yang mengikat dirinya untuk membayar harganya berupa uang kepada pemilik".

Pasal 1457 KUHP menyebutkan : jual beli merupakan persetujuan menyerahkan barang yang mempunyai nilai, dimana salah satu pihak menjual baragn tersebut, dan pihak lain membelinya dengan kesepakatan.

Dari ketentuan pasal 1457 KUHP ini dapat suatu kesimpulan bahwa perjanjian jual beli itu adalah perjanjian timbal balik, artinya masing-masing pihak mempunyai hak kewajiban sebagai akibat perjanjian yang dibuatnya, misalnya si penjual wajib menyerahkan barang yang telah dibuatnya, misalnya si penjual wajib menyerahkan barang yang telah dijualnya, dan sekaligus ia berhak juga atas pembayaran yang diberikan si pembeli. Sedang si pembeli wajib membawa harga yang diterimanya dari si penjual dan dan sekaligus pula ia berhak atas barang yang diserahkan oleh penjual tadi. Oleh karena itu, perjanjian jual beli ini berlainan dengan perjanjian yang disebut dalam pasal 1313 KUHP, yang berbunyi : "suatu persetujuan adalah suatu perbuatan dengan mana pihak yang satu mengikat dirinya terhadap satu orang yang lain atau lebih".

Jadi perjanjian dalam pasal 1313 KUHP ini adalah perjanjian sepihak, oleh karena mengikatkan dirinya hanya sepihak saja dan pihak lain tidak terikat atas perjanjian yang dibuatnya.

Perjanjian jual beli yang bersifat imbal balik itu sesuai dengan istilah hukum dalam bahasa Belanda "koop 
enverkoop" yang juga mengandung pengertian bahwa pihak yang satu "verkop" (menjual) sedang yang lainnya "koop" (membeli). Dalam bahasa Inggris jual beli diebutkan dengan "sale" yang berarti penjual (hanya dilihat dari sudut penjual saja). Begitu pula dalam bahasa Perancis "vente" yang disebut juga penjualan, sedang dalam bahasa Jerman dipakai perkataan : kauf' yang berarti pembelian.

Dalam sistem KUHP, penjual harus menyerahkan hak milik atas barang yang diperjualbelikkan itu kepada pembeli, juga sebaliknya pembeli harus membayar harga yang menjadi objek perjanjian. Barang yang menjadi objek perjanjian jual beli tersebut harus tertentu, setidak-tidaknya dapat ditentukan wujud dan jumlahnya pada saat ia akan menyerahkan hak miliknya kepada si pembeli. Dengan demikian adanya syah menurut hukum jual beli mengenai panen akan diperoleh pada suatu waktu dari sebidang tanah tertentu.

Berdasarkan pengertian yang diterangkan di atas, dapat disimpulkan bahwa pengertian perjanjian pengikatan jual beli merupakan sebuah perjanjian pendahuluan yang dibuat sebelum dilaksanakannya perjanjian utama atau perjanjian pokoknya. Sebagaimana telah diterangkan tentang pengertiannya, maka kedudukan perjanjian pengikatan jual beli yang sebagai perjanjian pendahuluan, maka perjanjian pengikatan jual beli berfungsi untuk mempersiapkan atau bahkan memperkuat perjanjian utama/pokok.

Isi dari perjanjian pengikatan jual beli yang merupakan perjanjian pendahuluan untuk lahirnya perjanjian pokok/utama biasanya adalah berupa janji-janji dari para pihak yang mengandung ketentuan tentang syaratsyarat yang harus disepakati untuk sahnya melakukan perjanjian utamanya. Misalnya dalam perjanjian pengikatan jual beli hak atas tanah, dalam perjanjian pengikatan jual belinya biasanya bersi janj-janj baik dari pihak penjual hak atas tanah maupun pihak pembelinya tentang pemenuhan terhadap syarat-syarat dalam perjanjian jual beli agar perjanjian utamanya yaitu perjanjian jual beli dan akta jual beli dapat ditandatangani di hadapan pejabat pembuat akta tanah (PPAT) seperti janji untuk melakukan pengurusan sertifikat tanah sebelum jual beli dilakukan sebagaimana diminta pihak pembeli, atau janji untuk segera melakukan pembayaran oleh pembeli sebagai syarat dari penjual, sehingga akta jual beli dapat ditandatangani di hadapan pejabat pembuat akta tanah (PPAT).

Selain janji-janji biasanya dalam perjanjian pengikatan jual beli juga dicantumkan tentang hak memberikan kuasa kepada pihak pembeli. Hal ini terjadi apabila pihak penjual berhalangan untuk hadir dalam melakukan penandatanganan akta jual beli di hadapan pejabat pembuat akta tanah (PPAT), baik karena lokasi yang jauh, atau karena ada halangan dan sebagainya. Pemberian kuasa tersebut biasanya baru berlaku setelah semua syarat untuk melakukan jual beli hak atas tanah di pejabat pembuat akta tanah (PPAT) telah terpenuhi. Sebagai perjanjian yang lahir karena kebutuhan dan tidak diatur secara tegas dalam bentuk peraturan perundang-undangan maka perjanjian pengikatan jual beli tidak mempunyai bentuk tertentu.

\subsection{Perpindahan Hak Milik dalam Perjanjian Jual Beli}

Secara yuridis dapat dilihat bahwa jual beli merupakan perjanjian konsensuil melalui rumusan Pasal 1458 Kitab Undang-undang Hukum Perdata.

Uraian di atas, secara sederhana dapat dikatakan bahwa pada dasarnya setiap penerimaan, yang diwujudkan dalam bentuk pernyataan penerimaan, baik yang dilakukan secara lisan, maupun yang dibuat dalam bentuk tertulis, menunjukkan saat lahirnya perjanjian. Seringkali dalam praktek 
proses penawaran dan permintaan tersebut tidaklah demikian halnya, dengan makin berkembangnya kehidupan ekonomi umat manusia, di mana transaksi jual beli tidak hanya diselenggarakan di pasar tradisional saja, melainkan juga pada pasar swalayan, akan kita jumpai suatu keadaan bahwa seorang pembeli yang diberikan harga penawaran, tidak mengajukan keberatan, atas penawaran lebih lanjut, maupun melakukan penerimaan atas penawaran yang diajukan, melainkan secara langsung mengambil barang yang hendak dibeli. Dalam hal ini, orang boleh mengatakan bahwa pembeli tersebut dapat menyetujui penawaran yang diberikan oleh penjual barang tersebut. Dalam hal ini kesepakatan dianggap terjadi pada saat pembeli mengambil barang tersebut dan membayar harganya kepada penjual.

Kitab Undang-undang Hukum Perdata tidak secara tegas memberikan pengertian dari peristiwa perdata yang dimaksudkan, namun demikian jika kita kembali kepada hakikat dari peristiwa perdata dalam hubungan penyerahan kebendaan, secara sederhana dapat dikatakan bahwa yang termasuk dalam peristiwa perdata tersebut adalah perbuatan hukum berupa perjanjian yang dibuat oleh dua pihak dengan tujuan untuk mengalihkan hak milik atas kebendaan tertentu. Dalam konteks yang sederhana, perjanjian yang berhubungan dengan tujuan pengalihan hak milik dapat kita temui dalam ketentuan :

a) Jual beli, yang diatur dalam Bab V Buku III Kitab Undang-undang Hukum Perdata;

b) Tukar menukar, yang diatur dalam Bab VI Buku III Kitab Undang-undang Hukum Perdata;

c) Hibah, yang diatur dalam Bab X Buku III Kitab Undang-undang Hukum Perdata.

Selain perjanjian tersebut, dalam bentuknya yang lebih kompleks, di luar bentuk perbuatan hukum yang disepakati para pihak (dalam wujud perjanjian), peristiwa hukum dalam bentuk Putusan Hakim, maupun Penetapan Pemenang Lelang, yang tidak semata-mata bergantung pada kesepakatan pihak dapat menjadi alas perolehan hak milik.

Ketentuan serupa dengan jual beli yang disebutkan dalam Pasal 1459 Kitab Undang-undang Hukum Perdata tersebut juga dapat kita temui dalam ketentuan Pasal 1686 Kitab Undangundang Hukum Perdata, yang mengatur mengenai hibah, yang menentukan bahwa; Hak milik atas benda-benda yang termaksud dalam penghibahan, sekalipun penghibahan ini telah diterima secara sah, tidaklah berpindah kepada penerima hibah, selainnya dengan jalan penyerahan sesuai dengan pasal 612, 613 dan 616 KUHPerdata. Sedangkan dalam ketentuan tukar-menukar, memang tidak secara tegas dinyatakan dalam ketentuan mengenai tukarmenukar, walaupun demikian dengan merujuk pada ketentuan Pasal 1546 Kitab Undang-undang Hukum Perdata.

Dengan demikian jelaslah bahwa setiap perbuatan hukum perdata yang bermaksud untuk mengalihkan hak milik, harus memenuhi ketentuan sebagaimana digariskan dalam Pasal 584 Kitab Undang-undang Hukum Perdata. Dalam ketentuan tersebut dapat diketahui bahwa sebelum suatu penyerahan kebendaan, dengan tujuan untuk melakukan pemindahan hak milik dapat dilakukan haruslah ada terlebih dahulu suatu peristiwa perdata yang bertujuan untuk mengalihkan hak milik tersebut, yang dalam bentuk perjanjian dapat tertuang dalam wujud jual beli, tukar menukar maupun hibah.

Pada penyerahan terhadap suatu barang dari hasil jual beli ada ketentuan bahwa kewajiban menyerahkan suatu barang meliputi segala sesuatu yang menjadi perlengkapannya serta dimaksudkan bagi pemakaiannya yang tetap, beserta surat-surat bukti milik, jika itu ada (Pasal 1428).

Unsur-unsur pokok (assannsialiaa) perjanjian jual beli adalah barang dan harga. Dengan demikian, 
seperti yang diuraikan diatas bahwa perjanjian jual beli ini terjadi sejak adanya kata sepakat mengenai barang dan harga meskipun barang itu belum diserahkan dan harganya belum ditawar. Kata sepakat itu melahirkan adanya perjanjian tersebut dan biasanya kata sepakat itu diwujudkan dengan kata setuju.

Kedua belah pihak itu bertemu untuk mencapai kata sepakat. Dicapainya sepakat ini dinyatakan oleh kedua belah pihak dengan mengucapkan perkataanperkataan ataupun perbuatan dan ataupun bersama-sama menaruh tanda tangan di bawah pernyataan-pernyataan tertulis sebagai tanda (bukti) bahwa kedua belah pihak telah menyetujui segala apa yang tersebut diatas tertulis itu.

Menurut Suryodiningrat (1982 : 92), kata sepakat ialah "kecocokan antara kehendak kedua belah pihak yang akan mengadakan perjanjian". Misalnya A membutuhkan uang dan karena itu akan menjual seekor kerbau miliknya, dengan harga Rp. 500.000. Kebetulan B membutuhkan kerbau, dan menyetujui kerbau milik A dengan harga Rp. 500.000,-, maka terjadilah kata sepakat. Untuk mengadakan perjanjian jual beli kerbau dengan harga Rp. 500.000,antara A dan B.

Dari ketentuan pasal 1458 KUHP tersebut dapat penulis nyatakan bahwa dengan lahirnya kata sepakat maka lahirlah perjanjian jual beli tersebut, dan sekaligus pada saat itu pula menyebabkan timbulnya hak dan kewajiban antara pihak-pihak yang mengadakan perjanjian jual beli tersebut. Oleh karena itu pula maka perjanjian jual beli dinyatakan sebagai perjanjian yang bersifat konsensuil, sering pula disebut perjanjian obligator.

Kadang-kadang pula pihak yang mengadakan perjanjian tersebut, setelah lahirnya hak, kewajiban menganggap dirinya sudah mempunyai status yang lain, artinya sudah menganggap dirinya sebagai pemilik atas barang yang diperjanjikan tersebut, padahal belum karena pembeli akan menjadi pemilik atas barang tersebut setelah diadakan penyerahan atas barang yang menjadi obligator perjanjian jual beli tersebut.

Jadi kalau belum diadakan penyerahan, maka pembeli belum menjadi pemilik barang tersebut. Pemilikan baru berganti setelah adanya pemindahan hak milik atas barang tersebut. Pemilikan baru berganti setelah adanya pemindahan hak milik atas barang yang diperjual belikan itu. Ini berarti, sekalipun sudah dibayar harga barang dan pembayaran itu sudah diterima si penjual namun si pembeli belum berstatus sebagai pemilik barang yang bersangkutan sebelum diadakan penyerahan.

Mengenai penyerahan hak milik ini, perlu diperhatikan tentang wujud barang-barang yang akan diserahkan, karena penyerahan barang tidak bergerak, berbeda dengan penyerahan barang bergerak. Kalau barang bergerak penyerahannya cukup dilakukan dengan penyerahan secara nyata saja atau penyerahan dari tangan ke tangan, ataupun penyerahan yang menyebakan seketika sipembeli pemilik barang.

Dalam pasal 1459 KUHP disebutkan : hak milik atas barang yang dijual tidaklah berpindah tangan kepada si pembeli, selama penyerahannya belum dilakukan menurut pasal 612,613, dan 616. Menurut pasal 612 KUHP disebutkan bahwa : penyerahan kebendaan bergerak, terkecuali yang tidak bertubuh, dilakukan penyerahan yang nyata akan benda itu atas nama pemilik atau dengan penyerahan kuncikunci dari bangunan dalam nama kebendaan yang harus diserahkan, dengan alasan hak lain telah dikuasai oleh orang yang hendak menerimanya.

Dari ketentuan pasal 612 KHUP tersebut dapat diketahui bahwa penyerahan barang atau benda bergerak kecuali barang bergerak tak berwujud dilakukan dengan suatu penyerahan dari tangan ketangan, dengan tanpa 
formalitas tertentu. Kalau barang itu disimpan di dalam suatu gudang atau pada suatu tempat yang terkunci, penyerahannya cukup dengan menyerahkan anak kunci gudang itu.

\subsection{Pengertian dan Sifat Pemberian Kuasa}

Di dalam perkembangan kehidupan yang sudah sangat maju sekarang ini, terkadang seseorang sudah sedemikian sibuknya dengan berbagai kepentingan sehingga seringkali untuk menyelesaikan kepentingan-kepentingan tersebut, ia tidak dapat hadir sendiri secara fisik. Oleh karena itu ia memerlukan jasa orang lain didalam menyelesaikan kepentingannya tersebut.

Agar orang yang diserahi tugas untuk menyelesaikan kepentingannya tersebut, dapat bertindak atas namanya, maka dengan suatu perjanjian, ia menyerahkan kekuasaan atau wewenangnya. Oleh karena pemberian kuasa adalah merupakan suatu perjanjian, maka pemberi kuasa dan penerima kuasa dapat membuat surat kuasa yang sesuai dengan kesepakatan selain yang telah ditentukan oleh undang-undang.

Dalam kesepakatan pemberian kuasa terdapat beberapa sifat pokok yaitu penerima kuasa langsung berkapasitas sebagai wakil pemberi kuasa, pemberian kuasa bersifat konsensual yaitu dibuat berdasarkan kesepakatan dan kekuatan mengikat tindakan kuasa hanya terbatas pada kewenangan yang diberikan oleh pemberi kuasa, begitu juga dalam hal tanggung jawab para pihak dalam pemberian kuasa.

Berdasarkan ketentuan pasal 1792 KUHPerdata yang berbunyi : pemberian kuasa adalah suatu persetujuan dengan mana seorang memberi kuasa kepada orang lain, yang menerimanya untuk atas nama menyelenggarakan suatu urusan. Defenisi yang hampir sama diberikan oleh Suryodiningrat (1996: 10) sebagai berikut: "pemberian kuasa adalah perjanjian dimana seseorang memberi kesuasaan (kewenangan) kepada orang lain yang menerimanya dan untuk atas nama pemberi kuasa yang melakukan perbuatan hukum (undang-undang yang mengatakan "melaksanakan suatu urusan")".

Secara umum dapat pula dirumuskan bahwa pemberian kuasa berarti hanya untuk perbuatanperbuatan mengurus barang atau perbuatan mengurus saja, tidak untuk melakukan perbuatan hukum seperti : memindahtangankan, pembebanan dan sebagainya. Yang ini harus dilakukan dengan pemberian kuasa secara tegas menyebutkan perbuatan tersebut.

Dari pengertian di atas dapat diketahui, bahwa dalam pemberian kuasa ini, dimana seorang untuk menyelenggarakan sesuatu urusan tertentu guna kepentingan pihak pemberi kuasa. Sebagaimana perjanjian jual beli, sewa menyewa, maka pemberian kuasa sifatnya konsesualisme, artinya pemberian kuasa telah terjadi atau sah sejak adanya kata sepakat, diantara pemberi kuasa dengan penerima kuasa.

Dari pengertian pemberian kuasa dalam Pasal 1792 KUH Perdata tersebut maka dapat diambil kesimpulan yaitu :

a. Pemberian kuasa adalah suatu perjanjian.

b. Untuk melakukan suatu perbuatan hukum.

c. Adanya perwakilan, yaitu seseorang atas nama orang lain melakukan suatu urusan.

Dengan kata lain, suatu perjanjian pemberian kuasa haruslah memenuhi ketiga unsur pokok tersebut. Jika salah satu saja dari ketiga unsur pokok tersebut tidak ada, maka perjanjian yang diadakan, bukanlah perjanjian pemberian kuasa sebagaimana yang dimaksud oleh pasal 1792 KUHPer.

Dengan demikian, maka pembedaan atas ketiga unsur pokok tersebut, hanyalah sekadar pembagian untuk memudahkan pembahasan dan 
bukan mnerupakan suatu pemisahan, karena ketiga unsur pokok tersebut adalah satu kesatuan yang utuh dan bulat.

\subsection{Kewajiban Pemberi dan Penerima Kuasa}

Seperti dikemukakan pada uraian sebelumnya, bahwa perjanjian pemberian kuasa juga merupakan perjanjian timbal balik, maksudnya kedua belah pihak sama-sama mempunyai hak dan kewajiban. Hal dari salah satu pihak misalnya hak memberi kuasa merupakan kewajiban dari kuasa, sedemikian bahwa si kuasa tercantum pada kewajiban pemberi kuasa. Dengan demikian disamping adanya prestasi juga adanya angan prestasi (kontra prestasi).

Sebagaimana yang telah dikemukakan bahwa dalam semua perjanjian yang dibuat oleh seorang juru kuasa inilah yang menjadi pihak dan sebagai pihak inilah yang menjadi pihak dan sebagai pihak ini ia memperoleh segala hak yang memikul segala kewajiban yang timbul dari perjanjian itu. Bahwa pemberi kuasa berhak untuk secara langsung menggugat orang dengan siapa si kuasa telah bertindak dalam kedudukannya.

$\mathrm{Si}$ pemberi kuasa diwajibkan mengembalikan kepada si penerima kuasa semua persekot dan biaya-biaya yang telah dikeluarkan oleh si kuasa untuk melaksanakan kuasanya begitu pula untuk membayar upahnya, jika ini telah diperjanjikan. Jika si kuasa tidak melakukan suatu kelalian maka si pemberi kuasa tidak dapat meluputkan diri dari kewajiban-kewajibanya mengembalikan persekot-persekot dan biaya-biaya serta membayar upah tersebut. Sekalipun urusan tidak berhasil. Bahkan urusannya ia tidak berhasil, tidak dapat disalahkan kepada si kuasa, asal ia telah mengerjakannya dengan sebaik-baiknya dan bertindak dalam batas wewenangnya (Simanjuntak, 2015 : 320).

$\mathrm{Si}$ pemberi kuasa tetap wajib memenuhi semua kewajibannya terhadap juru kuasanya. Misalnya seorang pengacara yang tidak berhasil memenangkan perkaranya tetap berhak atas honorariumnya dan pengembalian semua persekot dan biaya yang telah dikeluarkan untuk kepentingan si pemberi kuasa (Simanjuntak, 2015 : 153).

Sebagai lanjutan dari ketentuan tersebut, pasal 1809 KUHPerdata menetapkan : begitu pula si pemberi kuasa harus memberikan ganti rugi kepada si kuasa tentang kerugiankerugaian yang dideritanya sewaktu menjalankan kuasanya, asal dalam hal itu si kuasa tidak telah berbuat kurang hatihati. Selanjutnya menurut pasal 1810 KUHPerdata, si pemberi kuasa harus membayar kepada si kuasa bunga atau persekot-persekot yang telah dikeluarkan oleh si kuasa, terhitung dari mulai dikeluarkannya persekot-persekot itu. Bunga ini sebagaimana telah dikemukakan adalah bungan moratif sebesar 6\% setahun.

Jika seorang kuasa diangkat oleh berbagai orang untuk mewakili suatu urusan mereka bersama, maka masingmasing dari mereka itu adalah bertanggung jawab untuk seluruhnya terhadap si kuasa mengenai segala akibat dari pemberian kuasa itu (ditentukan pada pasal 1810 KUHPerdata) kalau pasal itu dibandingkan dengan pasal 1811 KUHPerdata, maka ternyata keadaannya adalah sebaliknya yaitu dalam hal yang diatur oleh pasal 1804 KUHPerdata satu orang pemberi kuasa berhadapan dengan beberapa orang kuasa, maka dalam hal yang diatur oleh pasal 1811 KUHPerdata satu orang juru kuasa berhadapan dengan beberapa orang pemberi kuasa.

Dalam hal pertama, ternyata undang-undang menetapkan adanya tanggung jawab secara tanggung menanggung diantara penerima kuasa, sedangkan dalam hal yang terakhir ditetapkan bahwa beberapa orang pemberi kuasa itu bertanggungjawab secara menanggung terhadap si penerima kuasa. Mungkin yang terjadi 
pertimbangan bagi pembuat undangundang ada untuk memudahkan si kuasa dalam hal menuntut upahnya atau lainlain hal terhadap pemberi kuasa.

Akhirnya oleh pasal 1812 KUHPerdata ditetapkan bahwa si kuasa berhak untuk menahan segala apa yang menjadi kepunyaan si pemberi kuasa yang berada di tangannya, sekian lama hingga kepadanya telah dibayar lunas segala apa yang dapat dituntutnya sebagai pemberi kuasa. Hal yang diberikan kepada juru kuasa untuk menahan barang kepunyaan si pemberi kuasa, sampai yang terakhir ini memenuhi kewajiban-kewajiban terhadap si kuasa, dinamakan hak retensi, yaitu semua hak yang seperti yang diberikan juga kepada seorang tukang yang mengerjakan sesuatu pada barang seseorang.

Hak dan kewajiban Pemberi Kuasa dan Penerima Kuasa sebagai berikut :

a). Kewajiban Penerima Kuasa,

b). Melaksanakan kuasanya dan bertanggung jawab atas segala biaya, kerugian, dan bunga yang timbul dari tidak dilaksanakannya kuasa itu,

c). Menyelesaikan urusan yang telah dimulai dikerjakannya pada waktu pemberi kuasa meninggal dan dapat menimbulkan kerugian jka tidak diselesaikan,

d). Bertanggung jawab atas segala perbuatan yang dilakukan dengan sengaja dan kelalaian-kelalaian yang dilakukan dalam menjalankan kuasanya,

e). Memberi laporan kepada pemberi kuasa tentang apa yang telah dilakukan, serta memberi perhitungan segala sesuatu yang diterimanya,

f). Bertanggung jawab atas orang lain yang ditunjuknya sebagai penggantinya dalam melaksanakan kuasanya :

1). Bila tidak diberikan kuasa untuk menunjuk orang lain sebagai penggantinya,
2). Bila kuasa itu diberikan tanpa menyebutkan orang tertentu, sedangkan orang yang dipilihnya ternyata orang yang tidak cakap atau tidak mampu.

Hak penerima kuasa, mencakup : memenuhi perjanjian yang telah dibuat antara penerima kuasa dengan pemberi kuasa, mengembalikan persekot dan biaya yang telah dikeluarkan penerima kuasa, membayar upah kepada penerima kuasa, memberikan ganti rugi kepada penerima kuasa atas kerugian yang dideritanya sewaktu menjalankan kuasanya, membayar bunga atas persekot yang telah dikeluarkan penerima kuasa terhitung mulai dikeluarkannya persekot tersebut.

\section{PEMBAHASAN DAN PEMBAHASAN}

Seperti diketahui bahwa ada dua hal penting yang perlu diperhatikan dalam hal jual beli tanah, yaitu :

1. Subjek dan

2. Objek

Subjek dalam perjanjian jual beli tanah, adalah pihak penjual dan pembeli, baik perorangan maupun sebagai nadan hukum. Hal pertama harus jelas adalah calon harus berhak menjual tanah itu. Mengenal siapa yang berhak menjual suatu bidang tanah tentu saja adalah si pemegang yang sah dari hak atas tanah itu dan kuasanya.

Akibat hukum jual beli tanah yang dilakukan oleh seorang yang tidak berhak ada;ah batal demi hukum. Artinya sejak semula hukum menganggap tidak pernah terjadi jual beli. Dalam hal demikian kepentiangan pembeli sangat dirugikan. Sebab ia sudah membayar harga tanah itu kepada penjual, sedangkan haknya atas tanah yang dibelinya tidak pernah beralih kepadanya, walaupun mungkin ia telah menguasai tanah itu. Sewaktu-waktu orang yang berhak itu dapat menuntut lewat pengadilan supaya tanah itu diserahkan kepadanya. Tuntutan itu sangat beralasan sehingga pembeli tanah yang memberli dari orang yang tidak berhak tadi akan dipaksa mengosongkan 
tanah yang mungkin diatasnya sudah ada rumah yang dibangun dan ditempati.

Selanjutnya juga pembeli yang merupakan objek dalam perjanjian jual beli tanah tersebut haruslah orang yang dapat menerima dan menyerahkan dan hak atas tanah yang diperjual belikan.

Dengan demikian, penjual dan pembeli mungkin bertindak sendiri atau melalui kuasa, identitasnya harus jelas. Kalau penjual dan pembeli adalah orang (manusia), maka identitas itu adalah : nama, umur, kewarganegaraan, pekerjaan dan tempat tinggal. Semua itu dapat dibaca melalui kartu identitas diri, seperti Kartu Tanda Penduduk.

Bila penjual atau pembeli adalah badan hukum, maka identitasnya adalah : nama, bentuk badan hukum (perseroan terbatas, yayasan, perusahaan negara, perusahaan jawatan dan lain-lain, kedudukan pengurus-pengurusnya). Semua itu dapat diketahui dari akte pendirian/anggaran dasar dan peraturan perundanan yang membentuknya.

Dalam hal penjual atau pembeli bertindak melalui seorang kuasa, maka surat kuasa khusus untuk menjual harus ada. Kuasa umum yang menurut lazimnya hanya untuk tindakan pengurus tidak berlaku untuk dijual. Kuasa itu harus tegas dan jelas untuk menjual tanah yang akan dijual itu.

Bentuk kuasa harus tertulis, kuasa lisan sama sekali tidak dapat dijadikan dasar bagi jual beli tanah. Kuasa tertulis itupun minimal dilegalisasi oleh Camat/Notaris/Panitera Pengadilan Negeri.Perwakilan negara di dalam negeri. Lebih lagi bila surat kuasa itu dibuat oleh seorang notaris (Perangin, 1991: 4).

Kuasa di bawah tangan yang tidak dilegalisasi tidak dapat dipakai sebagai dasar. Sebab bisa menjadi penipuan karena surat kuasa itu bisa dipalsukan. Tetapi surat itu dibawah tangan yang dilegalisasi atau otentik kecil sekali kemungkinannya untuk dipalsukan, sebab ada pejabat umum yang terlibat dalam pemberian kuasa itu, yang tentu akan menyelidiki identitas dan wewenang pemberi kuasa dan penerima kuasa.

Surat kuasa itu harus bermaterai cukup. Akte di bawah tangan materainya Rp. 500.000,-. Sedangkan akte otentik tentu saja notaris sudah menyelesaikan pembayarannya bea materinya. Yang harus diperhatikan adalah akte kuasa yang dibuat di luar negeri. Surat kuasa itu harus terlebih dahulu diberi materinya di Indonesia. Caranya surat kuasa itu dibawa kekantor pos dan dibawa bea materinya sudah dibayar. Perlu diketahui bahwa surat kuasa yang dibuat di luar negeri, harus dilegalisasi oleh Kedutaan Republik Indonesia di negara yan bersangkutan.

Berdasarkan hal-hal tersebut di atas, maka jelas bahwa jual beli tanah melalui seorang kuasa mempunyai kekuatan hukum yang sama dengan jual beli yang dilakukan secara langsung oleh pihak-pihak yang berkepentingan, apabila dalam pemberian kuasa tersebut dilakukan sesuai dengan yang dikemukakan tersebut, yaitu dibuat secara khusus maksudnya untuk menjual tanah secara langsung dan dibuat tertulis dan diberi secara materai bila akte tanah dibawah tangan, dilegalisir bila dibuat di luar negeri serta diberi materai di Indonesia.

Hal ini sesuai dengan ketentuan KUHPerdata, bahwa pemberi kuasa bertanggungjawab penuh terhadap perbuatan hukum yang dilakukan oleh penerima kuasa, selama menerima kuasa melakukan tugas yang diberikan kepadanya sesuai dengan isi dan maksud pemberuian kuasa tersebut.

Hal kedua yang penting diketahui adalah mengenai objeknya. Objek jual beli atanah adalah hak atas tanah yang akan dijual. Dalam praktek tersebut jual beli tanah yang akan dijual secara hukum yang benar adalah hak atas tanah yang akan dijual bukan tanahnya. Memang benar bahwa tujuan pembeli dapat secara sah menguasai dan menggunakan tanah tersebut. Tetapi yang dibeli itu 
bukan tanahnya, tetapi hak atas tanahnya.

Dengan demikian jelas bahwa secara hukum yang dijual bukan tanah, tetapi hak atas tanah. Dengan kata lain objek jual beli ialah hak atas tanah, karena yang dijual (dibeli) adalah hak atas tanah, maka kita harus tahu pasti apa macam hak yang menjadi objek jual beli itu.

Untuk tanah yang sudah disertifikat hal itu dapat dilihat dalam disertifikat. Bagi tanah bekas hak sebelum UUPA berlaku yang belum bersertifikat dapat diketahui dengan mempergunakan ketentuan-ketentuan tentang peruhbahan atas hak atas tanah. Tetapi hal itu belum pasti. Sebab kepastiannya hanya terjadi jikalau kepala badan pertanahan nasional telah menegaskan konversi hal. Oleh karena itu biasanya disebut dengan "bekas hak milik adat" atau "bekas hak einggedom" dan lain sebagainya sesuai dengan buktibukti yang ada.

Menurut Pasal 19 Peraturan Pemerintah. No. 10 tahun 1961 tentang pendaftaran tanah, disebutkan bahwa setiap perjanjian yang bermaksud memindahkan hak atas tanah, harus dibuktikan dengan PPAT. Dengan demikian jual beli hak atas tanah harus dilakukan di hadapan PPAT sebagai bukti bahwa talah terjadi jual beli suatu hak atas tanah, PPAT membuat akte jual beli.

Tetapi dalam praktek jual beli tanah di hadapan PPAT, masih jarang sekali dilakukan oleh warga masyarakat, karena masyarakat belum mengetahui apa sebenarnya fungsi PPAT itu terutama di pedesaan. Sehingga ketentuan tersebut belum sepenuhnya diindahkan dalam praktek jual beli tanah dalam masyarakat Indonesia.

\section{KESIMPULAN DAN SARAN}

\subsection{Kesimpulan}

1. Jual beli tanah melalui seorang penerima kuasa mempunyai kekuatan hukum yang sah dan mengikat pemberi kuasa dan pihak ketiga yang bersangkutan untuk melaksanakan isi dari perjanjian tersebut. Hal ini adalah karena pemberi kuasa wajib melaksanakan perjanjian yang dibuat oleh penerima kuasa, selama penerima kuasa tidak melebihi wewenang yang diberikan kepadanya. Bila terjadi perselisihan maka yang menjadi pihak adalah pemberi kuasa dan pihak ketiga tersebut bukan penerima kuasa.

2. Bahwa terhadap masalah-masalah yang timbul sehubungan dengan jual beli tanah melalui seorang kuasa dalam persidangan pengadilan ditetapkan ketentuan KUHPerdata. UUPA No. 5 Tahun 1960 dan Peraturan Pemerintah No. 10 tahun 1961 tentang pendaftaran tanah.

\subsection{Saran}

1. Kuasa menjual tanah diperbolehkan penggunaannya sepanjang digunakan sesuai dengan substansi dari kuasa menjual tersebut.

2. Aturan tentang jual beli tanah harus dikhususkan, dalam sebuah peraturan tertulis berupa undangundang sehingga pelaksanaan jual beli tidak dapat disimpangi.

\section{DAFTAR PUSTAKA}

Budiono Herlien. Kumpulan Tulisan Hukum Perdata di Bidang Kenotariatan. Bandung: Citra Aditya Bakti, Bandung, 2008.

\section{Pengikat Jual Beli Dan}

Kuasa Mutlak. Majalah Renvoi, Edisi tahun I, No. 10, Bulan Maret 2004.

Mashudi H. dan M. C. Ali. PengertianPengertian Elementer Hukum Perjanjian Perdata. Cet.II, Bandung : CV. Mandar Maju, 2001. 
Perangin Effendi.Hukum Agraria di Indonesia, Suatu Telaah dari Sudut Pandang Praktisi Hukum. Jakarta: Rajawali Pers, 1991.

Poerwadarminta, W.J.S., Kamus Umum Bahasa Indonesia. Jakarta : PN. Balai Pustaka, 1984.

Prodjodikoro Wirjono. Hukum Perdata Tentang Persetujuan Tertentu, Cet VIII, Bandung : Sumur, 1985.

Simanjuntak PNH.Hukum Perdata Indonesia. Jakarta: Kencana Prenadamedia Group, 2015.

Subekti R. Aneka Perjanjian. Bandung : PT. Citra Aditya Bakti, 1995.

- Hukum Perjanjian. Jakarta : Intermasa, 2002.

KUH Perdata. Jakarta: Pradnya Paramita, 2006.

Subekti, R. dan R. Tjitrosudibio, Kitab Undang-Undang Perdata. Jakarta : Pradnya Paramita, 1983.

Supriadi.Etika dan Tanggung Jawab Profesi Hukum di Indonesia. Jakarta : Sinar Grafika, 2008.

Suryodiningrat R.M. Perikatan-Perikatan Bersumber Perjanjian. Bandung: Tarsito, 1996.

Suryodiningrat R.M. Asas-asas Hukum Perikatan. Bandung : Tarsito, 1982.

Suryono Leli Joko. Pokok-Pokok Hukum Perjanjian Indonesia. Yogyakarta : LP3M, 2014. 